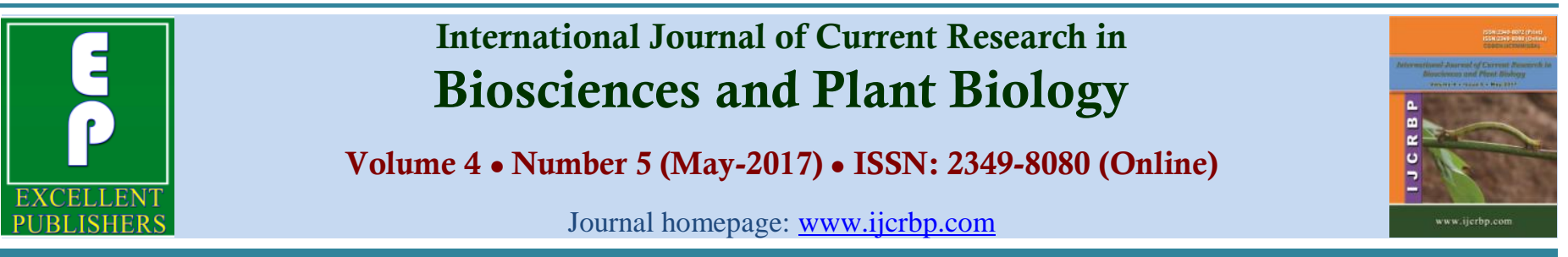

\title{
Legacy of Botany over Forestry
}

\author{
Arvind Bijalwan $^{1} *$ and Manmohan J. R. Dobriyal ${ }^{2}$ \\ ${ }^{1}$ Indian Institute of Forest Management, P.O. Box- 357, Nehru Nagar, Bhopal-462003, M.P., India \\ ${ }^{2}$ Department of Silviculture and Agroforestry, College of Forestry (ACHF), Navsari Agricultural University, Navsari-396 450, \\ Gujarat, India
}

*Corresponding author.

\begin{abstract}
The branches of plant sciences are basically originated from Botany thus it is considered as mother of plant sciences. Forestry is one such branch developed from Botany for specific purpose with its applied scope beyond the realm of Botany, however Forestry is still dominated by Botany even in the era of super-specialization.
\end{abstract}

\begin{tabular}{l} 
Article Info \\
Accepted: 30 April 2017 \\
Available Online: 06 May 2017 \\
\hline Keywords \\
\hline Botany \\
Forestry \\
Super-specialization
\end{tabular}

\section{Introduction}

Botany is considered to be mother of plants sciences as it covers wide range of organisms from the smallest bacteria to the largest plants like sequoia trees. In a broader sense botany includes algae, fungi, lichens, mosses, ferns, conifers and flowering plants (Whittakar, 1969). With the advancement of science, many applied subjects of plant sciences such as Agriculture, Horticulture, Olericulture, Floriculture, Forestry, Biotechnology, Genetics and Plant Breeding etc have been developed as separate branches. No doubt that the above subjects have originated under the umbrella of botany and gradually developed as specialized discipline to cater the need of subject. This kind of specialization has also happened in other major disciplines like Zoology with specialize branches of Veterinary, Biotechnology, Wildlife, Pathology, Entomology, Fisheries, etc. (https://en.wikipedia.org/wiki/Branches _of_botany). Here we would like to stress upon the fact that the new discipline is carved out for advancement purpose in the specific area, however many such disciplines could not recognize their identity as yet. One such discipline is forestry to advance as cutting edge science in India.

\section{Genesis of forestry}

The forests are the original habitat of all biological entities in terrestrial ecosystem and known for its significant role. Forestry though originated from botany in certain parameters but its scope is beyond the realm of plant classification, breeding, growth and development. Similarly, as science, forestry may not be older than agriculture but forest is considered foster mother of agriculture. Though, the concept of forestry was first emerged to know the forest in ancient period by monks and religious preachers as mentioned in 
Vedas. Later on commercial aspects of forests as a resource evolved, and thus lead to a separate branch of forest science and management in present form. Systematic management of forests for a sustainable yield of timber is said to have begun in Germany during 14th century followed by Japan in $16^{\text {th }}$ century. Hans Carl von Carlowitz wrote a book Sylvicultura Oeconomica (1713), as first comprehensive treatise about forestry (Young, 1982). During the late 19th century, forest preservation and management programs were established in India by Dietrich Brandis, the father of Indian forestry. This needs to be clarified that in initial years forestry in India was taught in training module to forest officers or foresters which confined to administrative set up of forest department only. Later, after 1980s forestry started an academic course in Indian universities and from 1985 onwards under Indian Council of Agriculture Research (ICAR), a four year professional degree as B.Sc. Forestry programme started along with M.Sc. Forestry and Ph.D forestry in State Agricultural Universities (SAUs). The current time is a period of super specialization where many branches are independently heading to show their impact in scientific fraternity; likewise, forestry / Forest science is also independently marching in different spheres of applied forestry.

\section{Inter-relation of Forestry and Botany}

It has been observed in the recent past that though Forest science have recognized and independently developed as specialized area but still by and large considered as a part of botany leads to selective exclusion and limiting the scope of forestry. Further botany is shadowing over forestry discipline in terms of silent scientific aggression beyond the subject of specialisation as well as specific tailored qualification based human resource pertaining to forest science or forestry institution. However, the reverse seldom happens even for specialize academicians and researchers in forestry be placed/ recruited in any institute of botanical sciences. Forestry is a separate branch dealing with forest resources creation, conservation, utilization and management still preludes to be a branch of botany. Even forest department with most of other scientific and academic institutes have the perception that forestry is part of botany so, any forestry problem will be dealt by either forest department or a botanist. The basic question is what should be the role of forestry professionals? The mindset of educationist, administrators and even policy makers is same for forestry as a branch of botany. The role of botany in forest sciences is to hold basic principles of plant science and taxonomy while the knowledge of professional forestry comprises the discipline of Silviculture, Agroforestry; Plantation Forestry; Silvicultural systems; Nursery management; Forest Mensuration; Tree Improvement, Forest Biodiversity \& Conservation; Tree Seed Technology; Forest Pathology; Wild Life Management; Forest Entomology, Tree Logging \& Ergonomics; Wood Products \& Utilization; Non-Wood forest products, Wood Science \& Technology; Medicinal \& Aromatic Plants, Forest Soil and Water Conservation; Soil Survey, Remote Sensing and Wasteland Development; Rangeland Management; Forest Management; Forest Policy and Legislation; Agro-meteorology; Forest Business Management; Marketing and Trade of Forest Produce; Forest Economics; Forest Project planning and Evaluation, Chemistry and Fertility of Forest Soils; Forest Engineering; Forest Tribology and Anthropology, Forest Extension and Climate change etc. It also includes the field training and experiential learning programme (Bijalwan and Dobriyal, 2015).

Now after analyzing the description of contents of forestry sub disciplines, it would have been clear that to put at par the Botany with Forestry is not a wise decision by academicians as well as administrators. It is a matter of deep concern that even after 30 years of academic journey of forestry in India, the forestry professionals having core degrees in forestry with super specialization in all the respective aspects has to justify themselves for forestry related assignments. The prevalence of the botany subject in the recruitment of forestry posts shows the unawareness about more than 25000 forestry graduates who are passed out in last decade in India and had a tag of professional degree by ICAR. In spite of these known facts even forest department, Ministry of Environment, Forest and Climate Change (MoEF \& $\mathrm{CC})$, ICAR and other sectors are listing Botany eligibility with specialization of forestry rather strictly restricting essential eligibility as forestry. The ICAR and Indian Council of Forestry research and Education (ICFRE) which are major stakeholders in forestry human resource recruitment are not able to clearly mention the forestry as essential degree rather keeping various specialization with botany or else. e.g. Botany with specialisation agroforestry, medicinal and aromatic plants, etc. and Forestry with specialisation agroforestry, medicinal and aromatic plants, etc. is not eligible in NARES/ARS. Similarly at entry level government advocating skill India but unlike agriculture graduates as 
agriculture officer, Horticulture graduates as Horticulture officers; Forestry graduates are not recruited as forest officer in rank of Assistant Conservator of Forests (ACF) or Range Forest Officer (RFO) or Deputy Ranger directly in forest department. Why in recruitment for research and teaching in forestry, the botany override on forestry just because of perception, it's a mother of plant science? Therefore, it is high time to advocate that during the recruitment of Forestry Scientists, Assistant Professors and other areas of forestry; Forestry students need to be preferred compared to botany students. Say for example, that to measure the dimensions of a tree or forest regeneration one need to have an idea of Forest Biometry or Silviculture which is not taught to a botanist, then how a person having master's or Ph.D. in botany will deem to be fit in forestry sector compared to the person having B.Sc., M.Sc. and Ph.D. in forestry. Contrary to this a candidate with forestry background is not considered to be fit in botany even though he/she has been taught all the courses of botany in forestry. Is this justice with forestry students by ICAR who even framed the model syllabus for M.Sc. Forestry and endorsed by ICFRE with specialization ranging from Agroforestry, Medicinal and Aromatic Plants, Environment management, Wildlife, Watershed management, Tree improvement, Forest genetics resources, wood science and technology, Forest business management, Forest Biotechnology etc but in recruitment for even ICAR, need a person from botany with agroforestry or specialized with medicinal plants.
This trend of double standard of policy makers with botany and sidelining of forestry specialization shows that superficially we concern for trees, climate change and environment, without giving due weightage to forestry professionals. In this scenario what is the significance of imparting specialize forestry degree and creation of separate council for forestry research and education (ICFRE) when their forestry knowledge is not utilized for the purpose? The transparency measures require from ICFRE itself to remove ambiguous approach against core forestry professionals. We are very positive and hopeful that in the era of super specialization to maintain the sanctity of the subject by clearly demarcating Botany and Forestry specialization to achieve the goal of sustainable development.

\section{Conflict of interest statement}

Authors declare that they have no conflict of interest.

\section{References}

Bijalwan, A., Dobriyal, M. J. R., 2015. Forestry as a career. Employment News, Govt. of India, 10-16 October 2015.

Branches of Botany, 2017. https://en.wikipedia.org/ wiki/Branches_of_botany.

Whittaker, R. H., 1969. New concepts of kingdoms or organisms" (PDF). Science. 163(3863), 150-160.

Young, R. A., 1982. Introduction to Forest Science. John Wiley \& Sons. ISBN 0-471-06438-6.

\section{How to cite this article:}

Bijalwan, A., Dobriyal, M. J. R., 2017. Legacy of Botany over Forestry. Int. J. Curr. Res. Biosci. Plant Biol. 4(5), 7476. doi: https://doi.org/10.20546/ijcrbp.2017.405.010 